The role of practice-based interventions in energy transitions : A framework for identifying types of work to scale up alternative practices

\title{
Laakso, Senja
}

2021-02

Laakso, S, Heiskanen, E, Matschoss , K, Apajalahti , E-L \& Fahy , F 2021, ' The role of practice-based interventions in energy transitions : A framework for identifying types of work to scale up alternative practices ' , Energy Research \& Social Science , vol. 72 , 101861 . https://doi.org/10.1016/j.er

http://hdl.handle.net/10138/327743

https://doi.org/10.1016/j.erss.2020.101861

acceptedVersion

Downloaded from Helda, University of Helsinki institutional repository.

This is an electronic reprint of the original article.

This reprint may differ from the original in pagination and typographic detail.

Please cite the original version. 


\title{
The role of practice-based interventions in energy transitions: a framework for identifying types of work to scale up alternative practices
}

\author{
Senja Laakso ${ }^{1 *}$, Eva Heiskanen², Kaisa Matschoss², Eeva-Lotta Apajalahti ${ }^{3}$, Frances Fahy ${ }^{4}$ \\ 1 Faculty of Educational Sciences, University of Helsinki, Finland, *corresponding author senja.laakso@ helsinki.fi \\ 2 Centre for Consumer Society Research, University of Helsinki, Finland \\ 3 Helsinki Institute of Sustainability Science, University of Helsinki, Finland \\ 4 School of Geography and Archaeology, National University of Ireland, Galway, Ireland
}

\begin{abstract}
Practice-based interventions have recently emerged as one way to question established practices and experiment with new, less energy-intensive ones within households. Yet, how practicebased interventions contribute to energy transitions on a larger scale still awaits to answer. The challenge is that practices are embedded in local conditions and contexts; therefore, scaling up is not simply a matter of multiplying or transferring particular solutions at new sites and larger scales, but it requires dedicated work to translate and support the local reinvention of practices. Drawing on insights from Social Practice Theory, Strategic Niche Management and Institutional Entrepreneurship, we build a conceptual framework for analysing the types of work needed to scale up alternative, energy saving practices in practice-based interventions. Based on the empirical investigation of six European practice-based interventions and the work conducted by the organisers, researchers, participants and stakeholders of these interventions, we identified three types of work to scale up: (i) proximate work to make the practice transferable; (ii) work to gain allies and resonance for the practice; and (iii) work to shape the conditions for scaling up. The paper serves as a valuable resource for future interventions, providing a framework for researchers and practitioners to support scaling up of alternative practices for low-carbon energy transition.
\end{abstract}

Keywords: practice-based intervention, energy consumption, household practices, real-life initiative, multiple-case study, scaling up

\section{Highlights:}

- Outlines a conceptual framework for work to scale up practice-based interventions

- Affirms the contingency and uncertainty of scaling up from small-scale initiatives

- Drawing on empirical evidence, the paper identifies 3 types of work for scaling up

- Shows how scaling up requires attention to external circumstances

- Offers suggestions for shaping the context and conditions for scaling up

\section{Introduction}


In recent years, there has been a dramatic growth in the number of initiatives that aim to steer energy consumption in a more sustainable direction, as communities, cities and nations are trying to meet the emission reduction targets and other sustainability goals (see, e.g. [1]). As the most popular policy measures focusing on for example information provision and 'technological fixes' [2] have not been able to change the consumption patterns rapidly enough, scholars such as Jensen et al. [3], Strengers et al. [4] and Welch and Southerton [5] have called for research and policy approaches that focus on daily household practices - the ways households for example keep clothes clean, apartments warm, take care of children, and go to work - and their relation to energy use, seeking for low-carbon alternatives for performing these practices.

As a distinction to behavioural approaches, drawing attention to practices means that instead of trying to motivate or persuade people to consume more sustainably or relying on more energy efficient technologies, researchers ask such questions as what is energy used for, what needs does it fulfil, and how can these needs be met with less energy use [6]. A practice-based analysis of consumption, furthermore, investigates what kinds of social expectations, norms and conventions underlie household practices and how these could be challenged [7]. This article focuses on such approaches that supported the reconfiguration of daily practices in households, which we call practice-based interventions (PBIS).

Despite PBIs have potential to challenge the present, energy-intensive daily practices within their contexts of implementation, their impact remains limited unless the new, alternative ways of performing a practice manage to engage more people to 'carry' them, and diffuse to other areas of daily life or outside the realm of households. Indeed, outside the household sphere, practices are shaped not only by households, but also by utilities, municipalities, and other institutions and their practices [6]. However, less attention has been dedicated to studying scaling up of alternative practices from PBIs [8] although previous research exists on mainstreaming the lessons from grassroots innovations and community-based initiatives (see, e.g., [9, 10]).

Taking insights from Strategic Niche Management, scaling up refers to processes of embedding innovations in mainstream ways of thinking, doing, and organising [11], or contributing to replacing the dominant structures [12]. This might occur in different ways, such as by taking the novel household practices or the intervention to other sites, increasing the number of participants in the intervention, linking up with other practices, technologies or reforms, or challenging and changing rules and regulations [13]. However, little is known about what kinds of work is involved in accomplishing such change; for example, how reconfigurations of practice embedded in local conditions gain wider cultural resonance, and how they are rendered transferable to other sites. When 
speaking of work, we refer in particular to institutional work by the organisers of the interventions, i.e., "the purposive action of individuals and organizations aimed at creating, maintaining and disrupting" institutions, such as dominant rules and practices in society [14, 215].

This complexity of scaling up engenders our research question: What types of work for scaling up can be identified in practice-based interventions? Six PBIs in Denmark, Finland, Germany and Ireland were selected for this study, as they aim to introduce alternative practices that are frugal in terms of energy and other natural resource use. Our research is focused on the work executed by several actors involved in these intervention in order to scale up alternative practices. While we acknowledge that addressing the conditions of PBIs is an important aspect of this work, the conditions, contexts or outcomes of the PBIs are left outside the scope of this examination. Therefore, by studying the work involved in scaling up of the practices in these initiatives, this study focuses on processes often left unaddressed. This allows us to provide a framework for researchers and practitioners to investigate and support scaling up of alternative practices, thus linking PBIs with larger-scale societal change and addressing topical issues of combining practice theories and transitions, as well as exploring the potential for fundamental changes in consumption [15].

In the next section, we outline our conceptual framework for analysing the mainstreaming of reconfigurations of alternative practices. Practice theoretical thinking is combined with insights from Strategic Niche Management and Institutional Entrepreneurship, to identify types of work required for scaling up, as well as the dependence of scaling processes on external conditions. In Section 3, we introduce the empirical material and analysis of our multiple-case study and introduce our cases in Section 4. Then, we present our results in Section 5, and discuss and elaborate our conceptual framework in Section 6. In the final section, we offer suggestions for addressing scaling up practices and the potential role of PBIs in sustainability transitions.

\section{Conceptual framework}

Our conceptual framework relies on three strands of literature. First, we discuss how the PBIs draw from the social practice theories (SPT). Second, we present processes of scaling up recognised in previous literature on Strategic Niche Management (SNM) and how they relate to literature on work in Institutional Entrepreneurship (IE) and SPT. Finally, we introduce the conceptual framework on which we later build our empirical findings on the types of work needed for scaling up. We recognise that these different bodies of literature draw on different ontological assumptions: whereas SPT are often said to adhere to a flat ontology [16], SNM and IE view the world as consisting of levels or 
fields exhibiting different degrees of structuration $[17,18]$. They also embody somewhat different views on human agency, where SPT downplay the role of individual agency and highlight the role of shared rules, whereas at the other end of the spectrum, IE focuses on individuals or groups who actively question and challenge shared rules. Since we are investigating interventions that aim to change the status quo, we perceive those organising the interventions as active agents, even though they are (from their own perspective) constrained by established practices, rules and social structures.

\subsection{Practice theoretical approach to interventions}

$\mathrm{SPT}^{1}$ has long roots in studies of consumption and everyday life (see e.g. [19]), as well as in studies focusing on energy use (e.g. [20,21]). They steer attention from isolated behaviours or technologies, to constellations of shared meanings, norms and rules, knowledge and competences, as well as materials and infrastructure, and the ways changes in these elements reconfigure practices [20, 22]. Practices-as-entities are recognizable sets of elements that can be spoken about and identified as shared practices, whereas routine actions - practices-as-performances - can be conceptualised as the reproduction of these social practices. Practices spread when (or if) they manage to 'recruit' new carriers [22].

In this paper, we call initiatives that have an explicit or implicit focus on introducing and experimenting with new or alternative forms of household or organizational practices, as practicebased interventions (PBIs) [23]. In PBIs, researchers and other actors, such as service providers and organizations, work together with households to bring practices into active deliberation and reflection, allowing people to innovate and experiment with different ways to achieve their daily needs (e.g. [24]) (see Figure 1, Box I).

What distinguishes these from more behaviour-based approaches is the way these interventions are conceptualized and executed, highlighting not only the individual motivations or new appliances, but linking these to practices and their social foundations, such as norms and cultural conventions, in a co-creative process. For example, by questioning the given, "normal” or default values for suitable indoor temperature, and learning to manage heating systems more actively and to heat bodies instead of space by wearing more clothes, practice-based intervention can support the introduction of more frugal heating practices and hence reductions in energy use. Interventions also acknowledge the role of organisational practices such as provision of energy or building management, linking practices in

\footnotetext{
${ }^{1} \mathrm{We}$ realize that theories of practice are very heterogeneous. In our interpretation of practice theories, we follow scholars such as Shove et al. [22] and Warde [19].
} 
the home with wider systemic processes [23]. Moreover, these interventions include elements such as new framings for frugal, energy saving practices and new ways of thinking about materials and technology, recognizing that alternative practices do not have to include novel technologies but reinvent "low-tech" elements from the past, such as those of adaptive indoor comfort, which can be innovative from the perspective of reducing energy consumption [25].

In addition to challenging established expectations toward indoor comfort, thus reducing demand for heating, these alternative practices include examples of people reducing the amount of laundry by questioning conventions of cleanliness and learning new ways to keep clothes wearable, such as airing [26], or learning new, less energy-intensive ways to fulfil their daily mobility needs, such as sharing rides [27, 28] (see Figure 1, Box II). Interventions can also involve simultaneous changes in a number of interlinked daily practices [29]. The potential of PBIs compared to other types of interventions (such as information provision or technological improvements) is that they help people to link the new knowledge, skills or technologies to daily practices, thus supporting the inclusion of environmental considerations in practices [30-32] in local contexts. However, in order to persist these practices need to be continually reproduced by those who do them, gain traction outside a limited number of households, and be embedded in the wider system of practices [33].

\subsection{Processes of scaling up}

To understand how PBIs are scaled up, our conceptual framework draws insights from SNM, and IE, in addition to SPT. SNM studies theorise on how innovative technologies are developed in protected spaces (niches) in order to break through into the mainstream [34] and have identified specific patterns of scaling up from niches [13]. SPT suggests that innovative practices needs to be reinvented and translated in new contexts $[35,36]$ and the literature on IE and institutional work focuses on how actors can actively shape the context and institutional rules in order for alternative practices to scale up [18]. Each of these three research streams bring insights on the type of work needed for scaling up, drawing on different disciplinary traditions. Below, we explicate how the combination of these three approaches builds up our conceptual framework, where we elaborate on four processes of scaling up from local experiments identified by Naber et al. [13]: growing, replication, accumulation, and transformation (see Figure 1, Box III).

Growing refers to the continuation of the experiment with more participants and on a larger scale, or classical diffusion. Such growth requires social interaction between existing and new participants 
[13], and potentially also social mobilisation and the ability to capture potential participants' interest [37].

Replication, in turn, refers to a process of scaling up where the main concept of the experiment is replicated in other contexts. However, research on the historical diffusion of innovations within the SNM tradition [38] suggests that innovative practices are not likely to diffuse as such, but need to be 'reinvented' in new contexts [35]. This notion is echoed by Shove and Pantzar [36] from SPT perspective, and also by Naber et al. [13], given that the 'main concept of the experiment' can be viewed rather flexibly. Moreover, literature on IE suggests that alternative practices deriving from a local, situated context need to be 'objectified', i.e., disembedded from the particularities of their original context, for example in the form of manuals or models, in order for them to become mobile and transferable, and make sense in another context [39, 40]. Similarly for Warde [41], the recognition and acceptability of a practice happens through procedures and artefacts, such as instructions and guidebooks, which allow the formalization of the practice.

Accumulation, according to Naber et al. [13], refers to a process where core elements from experiments are linked to other initiatives or complementary innovations, such as city developments or regulatory changes [42]. Hence, they become part of broader change processes. The importance of creating wide and diverse networks around the focal innovation is emphasised in the SNM literature (e.g. [34]) especially in contributions looking at intermediary activities (e.g. [43]), and SPT scholars highlight the importance of networks and communities, as well as the social significance of participation, when practices recruit carriers to perform and reproduce the practice [22]. Yet there is rarely much detail on how innovation advocates go about enrolling members to such networks. In contrast, IE has elaborated on the political and cultural work required to build up allies willing to challenge the status quo and introduce new rules and practices. Political work entails advocacy through social suasion, creating a network of 'insiders' and vested interested actors with certain roles and rights $[44,45]$. Cultural work, in turn, is required for the creation of legitimacy by framing the new practice to resonate with the cultural values of recipients [37, 46].

Transformation refers to a process where the experiment contributes to wider institutional change [13], which can occur in several ways. The conventional view is that research findings per se are taken up by policy makers, but this is rarely the case. Successful and popular experiments, however, can serve as performative evidence, which convince new advocates, including policy makers, that change is possible [47]. Difficulties encountered in local experiments can also serve to identify barriers and gaps in existing institutional frameworks, and create networks of advocates for change among those suffering from these barriers [13, 48]. As household practices are instituted and 
embedded in wider social, cultural, economic and material systems, the institutionalization of new practices may require changes in established rules, policies or processes, in order to legitimise them and facilitate their stabilisation [5, 49]. Furthermore, institutional change often depends on favourable conditions, such as tensions and crises in dominant institutions [44, 50, 51], and what the SNM literature refers to as 'windows of opportunity' [34]. Such windows require the temporal confluence of several events: sufficient problem awareness, mobilisation of advocate networks, and opportune political events $[44,52]$. Research on IE suggests that such windows can be exploited by those interested in institutional change in various ways: by biding their time for appropriate opportunities to arise, by actively framing issues and opportunities [53], or by reshaping their proposals in response to changes in institutional conditions [44].

\begin{tabular}{|l|}
\hline $\begin{array}{l}\text { Practice-based } \\
\text { interventions: }\end{array}$ \\
Engagement of \\
households and \\
stakeholders in \\
challenging and \\
changing energy- \\
intensive daily \\
practices in local \\
contexts
\end{tabular}

I

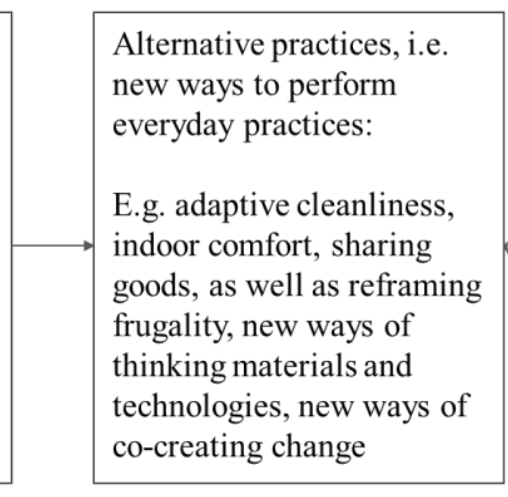

II

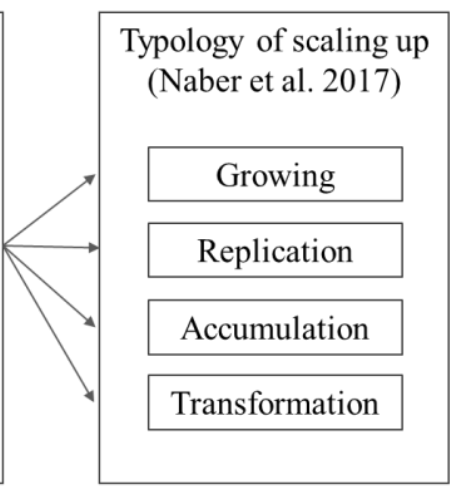

III

Figure 1. Conceptual framework for investigating the scaling up of alternative practices

Based on the literature review above, Figure 1 presents our conceptual framework. In the following sections, our empirical examination explores, validates and complements the suggestion that alternative practices do not occur on their own, but require dedicated work of several actors involved in the intervention.

\section{Research design, data and analysis}

To empirically validate and complement the conceptual framework (visualised in Figure 1), we conducted a multiple-case study on PBIs, focusing on (1) what scales up and how and, more importantly, (2) what the organisers of the intervention, participants and other stakeholders planned and did in order to promote upscaling. 
For our multiple-case study, we searched for suitable interventions from a database of European sustainable energy consumption initiatives [1]. Although the selected initiatives do not describe themselves explicitly as PBIs, nevertheless they take into account several aspects of practice, aim at changes in consumption by introducing alternative, energy-saving practices with the aim of reducing emissions, and engage households and communities as active participants, and thus can be called PBIs based on our definition. Further selection criteria were that the initiatives have documented their aims and ways of working and dissemination, and that material could be found on the implementation of their results. These criteria narrowed our selection to six initiatives that were included in our study. The cases exhibited various types and degrees of scaling up, allowing us to explore the work underlying these different outcomes (see Section 4 for the description of the cases).

Our data consist of both secondary data (project documents) and primary data (semi-structured interviews and observations). First, we reviewed all the data available online on the projects: project websites, news coverage, publicly available reports and academic publications. This process rendered a preliminary understanding of the work done for scaling up in each initiative. Second, we conducted semi-structured interviews with one or two key informants from each initiative: project leaders or principal researchers closely involved in the projects. The interview questions covered the contents of the intervention, alternative practices experimented with, processes of scaling up observed and conditions for scaling up of lessons learned, following our conceptual framework. The interviews were conducted by phone in May-June 2019 and each interview lasted approximately 45 to 60 minutes. Written summaries and recordings of the interviews were used to complement the initial findings from the other material. In addition, three of the authors participated in one project each as researchers, providing first-hand observations from three cases.

We recognize that the published materials are insufficient in providing information on how far the alternative practices are mainstreamed ${ }^{2}$, and the people implementing the projects and interviewed for this study may only have a partial view on how the alternative practices might have spread during or since the end of the projects. Hence, our aim is not to analyse the outcome of these PBIs, but rather the different types of work dedicated for scaling up and the problems faced in these projects, and thus to provide a framework for researchers and practitioners to support scaling up of low-carbon practices. Hence, we draw on methods for evaluating interventions whose outcomes and impacts have not yet fully materialized [54-56]. In such cases, initial insights can be gained by following the unfolding of the project managers" expected intervention logic or "theory in use" [54]; the pathways

\footnotetext{
${ }^{2} \mathrm{We}$ also recognize the methodological challenges in analysing practices or their up-scaling in quantitative terms (see also [2]).
} 
that project managers envisage for scaling up, and the existing evidence on whether these pathways are actually unfolding. This approach also partially addresses the problem of separating project outcomes from the outcomes of unrelated external events [57], by carefully tracing the unfolding of the project pathway [56].

Typically for case study analysis, first, we assembled case histories and conducted diachronic (i.e., case historical) analysis of the course of events in each case. We identified project managers' efforts and existing evidence of processes of growing, accumulation, replication and transformation, as well as their experiences from these efforts. We paid particular attention to uncovering the project managers' expected intervention logic [54], the types of work performed, the outcomes observed, and the reflections of project participants [58]. Then, we conducted a cross-case analysis to identify similarities and differences among the cases, and to understand the internal work and external factors influencing the conditions for scaling up.

\section{Case descriptions of the practice-based interventions}

All case studies were ambitious in terms of attempting to reduce household $\mathrm{CO}_{2}$ emissions, or overall resource consumption, by at least $25 \%$ by engendering changes in several types of household practices, described in Table 1 (cf. [15]). The initiatives involved several components of developing and experimenting with frugal practices, some technical and/or infrastructural support (e.g., advisors, meters, cargo bikes, free bus tickets), as well as engaged diverse groups of households and other actors in the co-creation of knowledge through deliberation about how and why practices could (or could not) change.

Table 1. Description of the cases of six European PBIs

\begin{tabular}{|l|l|l|l|}
\hline Name and location & Brief description $^{\mathbf{3}}$ & $\begin{array}{l}\text { Alternative practices } \\
\text { promoted }\end{array}$ & $\begin{array}{l}\text { Sources used for case } \\
\text { study }\end{array}$ \\
\hline $\begin{array}{l}\text { Ilmastotreeni } \\
\text { (Climate training), } \\
\text { Helsinki and } \\
\text { Vantaa, Finland }\end{array}$ & $\begin{array}{l}\text { Two four-week Home Labs with } \\
\text { three households each in an urban } \\
\text { area }\end{array}$ & $\begin{array}{l}\text { Practices related to } \\
\text { transport, eating, and } \\
\text { housing }\end{array}$ & $\begin{array}{l}\text { [59,60]; Project website } \\
\text { [61]; News coverage; } \\
\text { Observations by one } \\
\text { author; Interview/ project } \\
\text { manager, project } \\
\text { researcher }\end{array}$ \\
\hline
\end{tabular}

\footnotetext{
${ }^{3}$ The used terminology differs across PBIs (e.g. Home Lab, Neighbourhood Lab) and we opted to use the same terminology in this article as the organisers of the interventions, although we could also call them all PBIs. For example, Home Lab is the term given in the CONSENSUS project to experiments with households whereby a combination of socio-technical interventions were implemented within households with the aim of facilitating more sustainable washing and eating practices.
} 


\begin{tabular}{|c|c|c|c|}
\hline $\begin{array}{l}\text { CONSENSUS } \\
\text { Home Labs, Ireland }\end{array}$ & $\begin{array}{l}\text { Two Home Labs with five suburban } \\
\text { or rural households in each, over a } \\
\text { five-week period }\end{array}$ & $\begin{array}{l}\text { Eating and washing } \\
\text { practices }\end{array}$ & $\begin{array}{l}\text { [24, 62-66]; Project } \\
\text { website [67]; News } \\
\text { coverage; Observations } \\
\text { by one author; Interview/ } \\
\text { project leader }\end{array}$ \\
\hline $\begin{array}{l}\text { Energiesuffizienz } \\
\text { (Energy } \\
\text { sufficiency), } \\
\text { Heidelberg, } \\
\text { Germany }\end{array}$ & $\begin{array}{l}12 \text { people interviewed in } \\
\text { 'Neighbourhood Labs' in an urban } \\
\text { context, diverse group in terms of } \\
\text { household size, household } \\
\text { distribution, caretaker }\end{array}$ & $\begin{array}{l}\text { Co-creation of } \\
\text { suggestions for } \\
\text { alternative practices } \\
\text { based on identified } \\
\text { needs (focus on } \\
\text { laundry and watching } \\
\text { television) }\end{array}$ & $\begin{array}{l}\text { [68-73]; Project website } \\
\text { [74]; News coverage; } \\
\text { Interview/ project leader }\end{array}$ \\
\hline $\begin{array}{l}\text { Tulevaisuuden } \\
\text { kotitalous (Future } \\
\text { Household), } \\
\text { Jyväskylä, Finland }\end{array}$ & $\begin{array}{l}\text { Home Lab with } 5 \text { urban and rural } \\
\text { households of various sizes, with a } \\
\text { four-week experiment period }\end{array}$ & $\begin{array}{l}\text { Practices related to } \\
\text { transport, eating and } \\
\text { housing }\end{array}$ & $\begin{array}{l}{[28,29,31,75] ; \text { Project }} \\
\text { website }[76] ; \text { News } \\
\text { coverage; Participation } \\
\text { by one author; Interview/ } \\
\text { project leader }\end{array}$ \\
\hline $\begin{array}{l}\text { KlimaAlltag-- } \\
\text { Leben in der } \\
\text { NullEmissionsStadt } \\
\text { (Life in the zero- } \\
\text { emissions city), } \\
\text { Cologne and other } \\
\text { cities, Germany }\end{array}$ & $\begin{array}{l}78 \text { 'climate households' committed } \\
\text { to reducing their } \mathrm{CO}_{2} \text { emissions } \\
\text { through changes in everyday routines } \\
\text { during 6-month 'field test' in an } \\
\text { urban context }\end{array}$ & $\begin{array}{l}\text { Home energy use and } \\
\text { mobility practices }\end{array}$ & $\begin{array}{l}\text { [77-79]; Project website } \\
\text { [80]; Interview/ project } \\
\text { leader }\end{array}$ \\
\hline $\begin{array}{l}\text { Klimafamilier } \\
\text { (Climate families), } \\
\text { Ballerup, Denmark }\end{array}$ & $\begin{array}{l}20 \text { urban and rural households } \\
\text { experimenting with changes in } \\
\text { practices over a period of } 6 \text { months. } \\
\text { An extended version (with 6-7 } \\
\text { households) ran for } 3 \text { years }\end{array}$ & $\begin{array}{l}\text { Practices related to } \\
\text { food, transportation, } \\
\text { energy and water } \\
\text { consumption }\end{array}$ & $\begin{array}{l}\text { [81-84]; Interview/ } \\
\text { project researcher }\end{array}$ \\
\hline
\end{tabular}

Ilmastotreeni Home Lab was a part of a larger citizen engagement initiative that focused on change within the participating cities: in city administrations, among residents and local businesses [60]. Ilmastotreeni served as a concrete intervention that gave the project wider visibility. Families had a personal climate trainer and tailored training programmes, as they experimented with 'new practices, services and appliances that make everyday life easier'. Alternative practices promoted in this intervention included, for example, all-vegetarian meals supported by meal-box deliveries, and replacement of car use by cargo bikes and folding bikes.

CONSENSUS Home Labs intended to put into practice qualitative scenarios concerning eating and washing developed collaboratively with 80 stakeholders during participatory visioning and backcasting workshops [63]. The Home Labs sought to embed new practices in everyday life with a combination of motivational, informational, regulatory and product supports, and identified the need 
for cross-departmental collaboration in order to integrate education, policy, research, business and technology for a sustainability transition [24]. Alternative practices introduced by this project included reduced water use for showering and new food patterns, such as avoidance of food waste.

Energiesuffizienz focused both on the energy and appliance use in households, and on urban services and infrastructures that can support reduced natural resource use for household practices. The project also studied the acceptance and acceptability of decisions and activities on sufficiency in Germany, thus exploring the cultural resonance and legitimacy of the concept. Unlike other initiatives studied, Energiesuffizienz was not part of any wider programme [71]. It introduced alternative practices, for example, for replacing product ownership with shared services, sharing of space, car-free daily life and holidays, as well as more sustainable meals (e.g. reducing food waste, less meat, seasonal and local food).

The Tulevaisuuden kotitalous project engaged households in co-designing interventions, which the households then trialled. Local service providers were engaged to allow households to test their services, such as home-delivery of food, and to gain visibility locally. Public dissemination of the households' experiences through both conventional and social media channels formed a central element of the project. In this context, participants' experiences were presented as 'examples of what a "resource-wise" everyday life might look like' [29]. Alternative practices developed in this project included car and ride sharing as well as reduced living space.

Klimafamilier project was initiated by the city of Ballerup as part of the municipality's engagement in the Green Cities network and its commitment to reducing greenhouse gas emissions through citizens' engagement [82]. Households involved in the project were expected to serve as role models for a more climate-friendly way of life and they were indeed very engaged. The project introduced alternative practices to save energy, as well as the concept of 'citizen-driven climate action', i.e., the notion that citizens can work together to change their everyday lives [81].

KlimaAlltag aimed at finding ways of supporting, mainstreaming and normalising sustainable lifestyles in a socially just way [78]. The project focused on how climate protection is practised in everyday life and barriers to be overcome for further development, particularly in avoiding car use and air travel. This was supplemented by a survey in Frankfurt am Main and Munich. Innovative solutions developed included energy and climate advice tailored especially for low-income households, energy tariffs to incentivise energy saving, and mobility services to promote multimodality and more sustainable mobility routines. 


\section{Results}

In this section, we first analyse in more detail the processes and styles of scaling up based on the typology by Naber et al. [13], summarized in Table 2. Second, we discuss the work involved in each initiative, which we classify to work to make the practice transferrable, work to gain allies and resonance for the practice, and work to shape the conditions for scaling up.

\subsection{Processes and styles of scaling up}

\subsubsection{Growing}

Attempts to promote growing in the form of direct diffusion were visible in some, but not all projects. To support growing, alternative practices were disseminated in the form of social media posts, blog stories, videos, recipes or talks at events. In CONSENSUS, it was noted that the simplest interventions were often the most successful, as they were easy to try out and communicate, and simple for other households to copy:

'[...] it was often the most simple interventions - such as a 'eat-me-first' box in the fridge in combination with information about food waste [...] and the hypothetical increase in food waste costs [...] that householders embedded in their daily routines. These required little investment in time and resources as well as low levels of skill acquisition' (CONSENSUS project manager)

As an example of the scale of uptake, the 'how-to' videos posted by the Ilmastotreeni project in their website were viewed, on average100 times each during the first six months [60] and 14 news articles or stories were made about Tulevaisuuden kotitalous by both regional and national news [75]. Involving 'ordinary' people to interview and stories that people can relate to made these projects appealing for conventional media. In addition to published stories of 'how they did it', the Klimafamiljer families, for instance, organised events and made appearances at town events, together with the local Mayor [83].

\subsubsection{Replication}

Five out of six cases increased their number of participants through replication, in subsequent projects. Often, the organizers of the first intervention teamed up with new organizers for another, often larger project. For example, core ideas from the CONSENSUS project were replicated in a European research project (ENERGISE) involving more than 300 households, even though this new project focussed on different practices than the original project. Similarly, a partner in the KlimaAlltag project, the regional consumer advice centre Verbraucherzentrale Nordrhein-Westfalen, started a 
larger project together with other regional advice centres in ten municipalities across Germany. Additionally, the project resulted in two projects by other research groups, with about 100 participants each, in Frankfurt and Berlin. Tulevaisuuden kotitalous resulted in several similar projects in Finland reaching approximately 250 households by the end of year 2019, and resulting in an international project involving several countries and aiming to recruit 70,000 participants.

Replication also happened via existing networks. The Ilmastotreeni concept has been taken forward by the regional Climate Info advice service in the form of a web page where anyone can register for four-week climate training. The website also has an educational platform as well as a web course on sustainable living. The Energiesuffizienz project initiated several ensuing projects and networks on energy sufficiency, and energy sufficiency became one of the concepts used by energy advisors working with the support of the federal government's National Climate Initiative. These observations suggest that the first projects are often about learning to conduct the intervention (cf. [13]), and subsequent projects can have larger scales and involve larger numbers of organisers and participants.

\subsubsection{Accumulation}

Accumulation was a central part of several PBIs, in particular ones that were embedded in, and aimed to support, local sustainable development initiatives. Examples of accumulation included, e.g., integration into civil society campaigns on mobility and climate friendly food, energy advice and energy-saving tariffs provided by energy companies, and climate advice provided by regional consumer advice centres (Ilmastotreeni, KlimaAlltag). In these, it was not so much the practices of original participants, but rather the (simple, but unconventional) way of working that was adopted by other organisations:

'Build up a dialogue to give people the opportunity to change something, question routines, try to make experiments, try to do something different and collect people's experiences' (KlimaAlltag project manager).

Accumulation could also occur by building links to energy co-operatives, the professional practice of designers and design students, as well as integration into urban planning guidelines, as in the Energiesuffizienz project. In Ilmastotreeni, practice change was linked to the development of energy monitoring and saving devices, as well as to product and marketing development of alternative mobility (e.g., cargo bikes, folding bikes) and meal services (e.g., home delivered meal ingredient packages).

\subsubsection{Transformation}


All projects aimed at some degree of transformation, or institutional change, at a minimum to convey the message that change toward more sustainable practices is possible. Some, like Ilmastotreeni, as part of the broader initiative, aimed mainly to change such local institutions as urban planning regulations, though successes were rather small-scale (e.g., improved parking for cargo bikes). Also, Tulevaisuuden kotitalous organised a final event with the aim to engage stakeholders in both public and private sectors to embed "sustainable lifestyles thinking" in their practices, however, it is difficult to estimate whether the event had any concrete outcomes.

Others, like Energiesuffizienz, developed detailed policy proposals, for example, for national energy sufficiency [71] and sustainable housing policies [73], thus intensifying the debate on the need for sufficiency policies. Also the CONSENSUS project developed recommendations for sustainable consumption policy, focusing on particular sectors (such as teleworking) and levels of government (such as local authorities), but also on a more general, agenda-setting level. Examples of successes mentioned included influencing national energy and water policies to include notions of sufficiency and practice change (CONSENSUS) and inclusion of funding for practice change initiatives in national funding schemes (KlimaAlltag).

Table 2. Summary of the types of scaling up observed

\begin{tabular}{|c|c|}
\hline Name & Types of scaling up observed \\
\hline Ilmastotreeni & $\begin{array}{l}\text { Growing: Sharing of experiences via videos and blogs } \\
\text { Replication: Some aspects replicated in web platform format } \\
\text { Accumulation: Linking to a larger urban redevelopment project, inclusion in design } \\
\text { and marketing of alternative services }\end{array}$ \\
\hline CONSENSUS & $\begin{array}{l}\text { Accumulation: Part of broader research project including large-scale surveys as well } \\
\text { as collaborative backcasting and scenario development with users } \\
\text { Replication: Leading to a large European project in eight countries } \\
\text { Transformation: Reshaping policy concepts and measures for sustainable } \\
\text { consumption }\end{array}$ \\
\hline Energiesuffizienz & $\begin{array}{l}\text { Accumulation: Linking to sustainable service design, integration into urban } \\
\text { planning guidelines } \\
\text { Replication: several ensuing projects } \\
\text { Transformation: Concrete manifestation of energy sufficiency concept served to } \\
\text { diffuse the concept in the research, practice and policy communities and project } \\
\text { funding criteria, influence on national policy formulation and regional energy } \\
\text { advice }\end{array}$ \\
\hline $\begin{array}{l}\text { Tulevaisuuden } \\
\text { kotitalous }\end{array}$ & $\begin{array}{l}\text { Growing: Sharing of experiences via social and local media } \\
\text { Accumulation: Part of regional programme } \\
\text { Replication: Several subsequent projects, eventually at a much larger international } \\
\text { scale }\end{array}$ \\
\hline
\end{tabular}




\begin{tabular}{|l|l|}
\hline & $\begin{array}{l}\text { Transformation: Opportunities and barriers to change communicated to policy } \\
\text { makers }\end{array}$ \\
\hline KlimaAlltag & $\begin{array}{l}\text { Accumulation: Engagement of climate advisors and city agencies and utilities } \\
\text { Replication: Similar projects in other cities } \\
\text { Transformation: Changes in the structure of energy advice provision, fine-tuning of } \\
\text { energy tariff structures, changes in criteria of funding bodies }\end{array}$ \\
\hline Klimafamilier & $\begin{array}{l}\text { Growing: Active co-design by households (e.g., a cookbook), sharing experience } \\
\text { with other citizens }\end{array}$ \\
\hline
\end{tabular}

\subsection{Work to make alternative practices scalable}

\subsubsection{Work to make the practices transferable,}

All interventions anticipated the need to transfer lessons learned in their project to a wider audience. Effort was devoted to make the lessons learned in the intervention transferable via videos, blogs and other elements that were easy and attractive to communicate in the media, such as carbon footprints and stories of the participants' experiences in Tulevaisuuden kotitalous, 'self-help' material as in KlimaAlltag, online videos produced by the Ilmastotreeni households, or a cookbook produced by the Klimafamiljer families. In several projects, the households were made 'climate heroes' whose stories everyone could identify with. This is also illustrated by the ways the interventions were described as examples, showcases and testbeds, or as discussion starters or 'food for thought'.

Although the role of the participants in sharing their experiences via different media, thus contributing to diffusion, was important in almost all of the projects, in some cases (such as Tulevaisuuden kotitalous), the households gained little support for dissemination activities and some of them felt rather helpless in this regard [28]. Similarly, Klimafamiljer households were very engaged in the project but encountered continuation problems in support from the local government [83, 84]. For practices to become transferable, active work was thus required also outside the participating households.

Our findings suggest that transferable tools and concepts (such as guidebooks, planning templates or visualisations 'formalizing' the practice [41]) were more easily taken up if they were developed together with participants and other stakeholders. For example, in KlimaAlltag, training was organised and networks created with existing consumer advice bodies, which had previously organized advice separately for e.g. energy and nutrition, in order to codify the concept into a manual for holistic climate advice. In Energiesuffizienz, various stakeholders, such as policy makers, city administration, businesses and citizens, were involved from the beginning in co-defining, and further co-developing, the concept of energy sufficiency and workshops were organised to co-design the 
policy packages and instruments to contribute to sufficiency practices. Students from design and architecture engaged representatives from local administration in order to gain proponents and multipliers for their new ideas and to develop them further. Indeed, one of the aims of the project was to "develop and support "islands" with pioneers, who create different new models and can become multipliers' [71]. Work to make alternative practices transferable is very much related to work to gain allies and cultural resonance, presented in the following, and in some occasions they are overlapping.

\subsubsection{Work to gain allies and cultural resonance}

Almost all projects recognised the need to identify and engage stakeholders early on in order to gain allies, in line with the previous work highlighting the importance of networks [34]. Yet, the strategies to achieve this goal were very diverse. There were a large number of collaborators and stakeholders in all projects except in Klimafamiljer, in which the only actors involved were the municipality and the families - and in which the scaling up was limited to growing, in Naber's et al. terms [13]. Other projects, in turn, addressed rather diverse sets of stakeholders, including businesses, utilities, local and national administrations and NGOs, with the aim of linking alternative practices with wider systems (cf [5]). KlimaAlltag, for example, actively engaged specific practitioners throughout the research, developing the professional practice of local consumer advisors toward a climate focus, urban planners, facility managers and utilities in a more user-friendly direction, gaining proponents for multiplying the lessons of how everyday practices can take form in a climate friendly way [79]. In Ilmastotreeni and Tulevaisuuden kotitalous, the local companies were seen as relevant stakeholders, as they were able to test their products and services with the households, and in this sense, the intervention also served to get business on board in the long term:

'Funding [from external source] made it possible to have companies on board to provide services such as home delivery of food or a car sharing service for households to test for free. This kind of funding has not been available in later projects, but on the other hand, the experiences from the first project have encouraged companies to join even without reimbursement. The companies also receive valuable feedback from households and can improve their services.' (Tulevaisuuden kotitalous project manager)

Other projects, like CONSENSUS and Energiesuffizienz, focused more on the development of nationwide cultural resonance and legitimacy. For example, in CONSENSUS, topical concerns over economic adversity and quality of life were identified as creating resonance for discussions about different, less resource-intensive ways of life [65]. However, such deep-seated questioning of basic assumptions about well-being was rare at the time. Despite the household-level action, national and 
local policy makers were the main addressees for introducing institutional change and the project also included regular face-to-face interactions with policy makers [66]. CONSENSUS was particularly interested in promoting conceptual utilisation, such as awakening the imagination of policy makers to the possibility of complementing efficiency targets with goals for a cultural change in everyday consumption practices. KlimaAlltag, in turn, gained resonance in the national policy debate concerning Germany's nuclear phase out and a search for ways to put it into practice in the everyday life of ordinary people, illustrating the significance of political, policy and media practices, and their temporal dynamics, for interventions:

'This genre is very popular in Germany, I would call it Ratgeber (self-help), how to improve your life, how to change. This is very attractive to the media. This was what they found attractive, as well [...] as the connection to the ongoing political debate on nuclear, the energy turnaround (Energiewende), and finding ways to bring back the discussion from the technical side to the everyday and mundane - these made our project very attractive.' (KlimaAlltag project manager)

However, several projects sought resonance with the cultural values of a rather narrow group of stakeholders. As one example, Ilmastotreeni developed cultural resonance and legitimacy within a small circle - in this case, of modern urbanites - but the PBI experiences mostly failed to communicate credibly with more conservative residents, businesses, building owners and city officials outside of the project's direct sphere of influence [60]. KlimaAlltag was the only intervention among our cases that explicitly focused on low-income households. Moreover, we found only few examples of attempts to develop legitimacy in other areas besides sustainability concerns, apart from the following observation:

'Through sufficiency one doesn't need to create more work for households, one could actually reduce the burden of housework practices and, at the same time, save energy.' (EnergieSuffizienz project manager)

The types of cultural values that interventions draw on can reflect on the kinds of allies they manage to engage, and vice versa. Work with a limited group of dedicated allies can give interventions a good start, but can turn into a barrier for scaling up if only pre-existing networks are engaged. Gaining broader resonance - for example, with low-income households or people with other immediate concerns except for sustainability - may require input from different kinds of allies. This highlights the challenges of reinventing practices in new contexts without devoted allies (cf [13]). 


\subsubsection{Work to shape the conditions for scaling up}

PBIs go against the grain of current technical, commercial and political systems, and therefore they naturally encounter resistance when attempting to gain transformation on a wider scope. However, within the prevailing system, there are more or less protected spaces where new ideas and practices can grow. In our data, all projects paid attention to finding (at least local) contexts where problem awareness and political opportunities allow for policy change. Timing was considered essential, either supporting the project or forcing it to change focus. For example, CONSENSUS gained funding as the global recession of 2008 hit in Ireland. While the project funding itself was not impacted negatively, austerity measures affected the project focus and shaped both householders' responses to the engagement and policy makers' interest and engagement in the research conducted. However, the research also became more topical with respect to the government seeking to be more resource efficient, but it also made policy makers (as well as households) cautious about promoting frugality:

'While the proposal had focused on the consumption challenges resulting from a period of abundance, the application took place under conditions of austerity that endured for a decade and which covered the research period. Indeed, austerity measures around water charges, for example, materially affected the project focus and shaped both householders' responses to the engagement and policy makers' interest and engagement in the research.' (CONSENSUS project manager)

These observations suggest that project leaders can enhance the intervention's fit with its environment by adapting the intervention to changing conditions. We also found some examples of work by project teams to identify crises and tensions in the dominant institutions, as well as complementary trends and innovations that open up windows of opportunity (cf [34]). Energiesuffizienz, KlimaAlltag and Tulevaisuuden kotitalous managed to exploit the beneficial conditions and rising climate policy interest, thus creating a positive spin leading to further initiatives. Windows of opportunity could also be supported by complementary innovations, as in Ilmastotreeni, where experimentation with practice-based change was linked to experimentation with, for example, smart energy devices, PV installations in apartment buildings and energy renovation services. More explicitly, the back-casting exercise in the CONSENSUS project elaborated Transitions Frameworks, which identified both policy measures and current innovative trends that might support the envisaged transitions [62]. Overall, these served to communicate that transitions in consumption are lengthy processes that require a longterm, collaborative approach [66]. 
Based on our empirical examination of the PBIs, we complement the conceptual framework by adding the types of work needed to scale up that occur in parallel with processes of scaling up (in Figure 2, Box IV).

\begin{tabular}{|l|}
\hline $\begin{array}{l}\text { Practice-based } \\
\text { interventions: }\end{array}$ \\
Engagement of \\
households and \\
stakeholders in \\
challenging and \\
changing energy- \\
intensive daily \\
practices in local \\
contexts
\end{tabular}

I

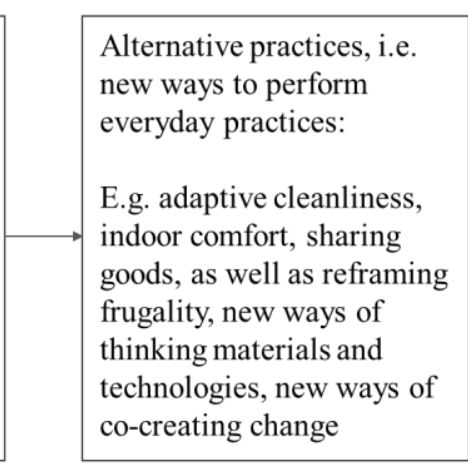

II

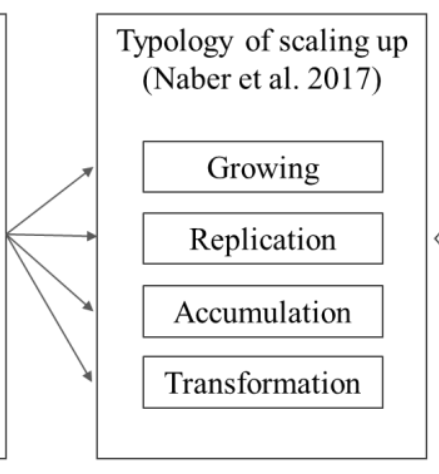

III

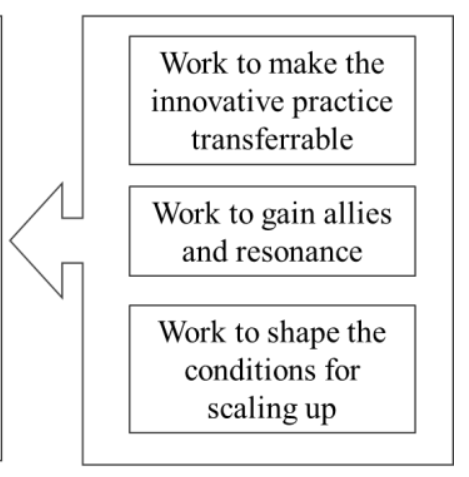

IV

Figure 2. Empirically elaborated framework for investigating the scaling up of alternative practices

\section{Discussion}

Our analysis shows that the PBIs clearly served their purpose in proposing solutions to facilitating practice change, influencing problem awareness, identifying barriers to change, and highlighting the relationship between consumption, production and policy practices. In many cases, they could demonstrate the interlinkages between technologies, infrastructures, social norms and skills in alternative practices (see also [32]). They also managed to disseminate novel ideas such as energy sufficiency or sustainable lifestyles, leading to a number of new initiatives in new contexts. By cocreating alternative practices together with households and other actors, the PBIs made change more doable and accessible for practitioners and policy makers promoting sustainable consumption. Addressing practices and the ways they are instituted and embedded in wider systems [5] can also support the identification of root causes and critical problems of ongoing transition, supplementing the existing approaches in policy interventions [85]. However, the findings illustrate how the utilization of PBI results requires many types of work from their organizers.

All of our cases of PBIs engaged in proximate work to make the alternative practices transferable, and this was clearly what the project managers knew best how to do. They were good at creating tips, advice pages, videos, blog posts, manuals, training programmes and online courses, often working in collaboration with households, to objectify and formalize elements of practice to enable their reinvention in other contexts [39-41]. In addition, they were all proficient in involving the participating households in co-designing the intervention in order to embed research ideas into local 
people's concerns and practices. Nevertheless, the unmet expectations regarding peer diffusion from the participating households to other households in some of the interventions underline how articulating alternative practices or 'new normals' can be much more difficult than, for example, advertising new technical innovations [47].

Rather than direct diffusion, our cases confirm the need for reinvention of practices when they are transferred to new sites, thus emphasising the spatio-temporal grounding of the alternative practices $[36,38,86]$. In order to spur such reinvention, the interventions needed to gain allies and professional networks to carry and refine knowledge, techniques, procedures and rhetoric concerning the innovation, as well as to develop cultural resonance for the alternative practices. Moreover, practitioners and policy makers needed to be closely involved in PBIs in order for them to shape the conditions for scaling up and lead to institutional change (see also [49]). There were differences among the case interventions in how they engaged stakeholders and worked to gain proponents to multiply and reinvent the alternative practices, for example, by involving various local and national government agencies. Successful cases sparked the imagination of (local) government officials and agencies through the performance of PBIs, and by actively involving agencies and their concerns, rendered new and different combinations of everyday practices more credible, legitimate and feasible for policy support. These findings highlight the need to address the interlinkages between practices of consumption and those of supply, policy and governance, when scaling up alternative practices (see also [5, 30]). More practically, they also suggest that PBI organisers might benefit from thinking in terms of allies, rather than just stakeholders, by actively identifying who or what needs to change for alternative practices to mainstream [27] and engaging potential multipliers and service providers as partners from the start.

It is very difficult for projects with external research funding and a limited timespan to hit the exact right time when there is a confluence of problems, opportunities and solutions. Some of the PBIs covered herein were rather short-term and subject to collective temporal dynamics (see also [86]. Therefore, continuity was identified as critical, either in the form of creating some kind of stable community that carries the development forward, by consolidating the alternative practices in roadmaps and guidebooks for particular users, or in terms of new research projects. In new projects, the involvement of practitioners from the start seems to be critical, as well as the creation of concrete steps and skills for the stakeholders to provide direction for future behaviour. However, not all PBIs left a legacy of concrete steps (e.g., a roadmap) for the stakeholders on how to proceed, although these kinds of tools were identified as essential for alternative practices to take root. We could also identify several new projects that had gained inspiration from the interventions under study. Many of 
these were similar in size to the original intervention, but there were also examples where the intervention was replicated in new countries, on a much larger scale and even on sites where previous experience of such PBI is lacking.

The framework by Naber et al. [13] was originally developed for innovations with a stronger technical component (smart grid initiatives). However, it offered valuable insights for investigating practicebased interventions, which were not focused on particular technologies but combinations of household practices. Our framework for analyzing the work on the ground performed by intervention organizers together with participants and stakeholders offers additional insights on processes of scaling up, and the kinds of resources and skills this requires. Our conceptual framework allowed us, for example, to identify how some interventions focused on "growing", which might not be the primary pathway for alternative practices to gain ground in a largely unsupportive institutional environment. However, we also noticed that some of the measures taken by intervention organizers to support "growing" were actually important for gaining allies and making the alternative practices transferable. Our conceptual framework also highlighted the importance of gaining allies in order to allow the interventions a longer period of time to attempt to scale up, and wait for better temporal conditions for scaling up. In this way, we offer more specificity to the concepts of networking and learning, which are popular in the SNM literature underlying the framework by Naber et al. [13].

There are some obvious limitations to our study. We have only been able to investigate the process of scaling up, whereas the identification of outcomes would require a long-term historical analysis, and would still involve uncertainties in attributing changes to our case initiatives [57]. Further elaboration of the framework proposed by Naber et al. [13], as well as our own categories of institutional work for scaling up interventions, could extend to conceptualizing outcomes, and relating processes more firmly to outcomes, once more long-term historical data becomes available. We also have not been able to investigate the scaling up of entire practices, but rather various elements of alternative practices and intervention components. Moreover, since our empirical data are limited and based on only six in-depth case studies of European PBIs, further research is needed to validate our framework of processes of scaling up with larger datasets and beyond the European context. We also acknowledge that we have taken the intervention organizers' perspective, rather than that of participants or the practices themselves. This has been necessary in order to offer wide learning points and help demonstrate the work necessary - and feasible - towards mainstreaming alternative practices. 


\section{Conclusions}

In this article, we have combined insights from SPT, SNM and IE to construct a conceptual framework for studying processes and the work involved in scaling up alternative practices that aim to achieve reductions in everyday energy use, taking part in the discussion on how interventions might contribute to deep changes in consumption and thus to sustainable energy transitions. To empirically validate and complement the conceptual framework, we conducted a multiple-case study on six European practice-based-interventions (PBIs). We find that work involved in scaling up includes work to make the practice transferrable, work to gain allies and resonance for the practice, and work to shape the conditions for scaling up.

The results and the conceptual framework presented in this article offer insights for practitioners for planning and implementing interventions, and for addressing the contingency and uncertainty of scaling up from small-scale initiatives as our empirical analysis indicated that there is identifiable work that PBIs can do to increase their chances of scaling up. Our observations highlight the importance of engaging a diverse range of people and social groups in PBIs, and, in particular, in the way project findings are communicated. Our cases also illustrate the significance of developing alliances and networks beyond the participating households for continuity.

Our findings underline the need for a more fine-grained analysis of stakeholder participation: are stakeholders just 'bystanders' or do they find a genuine role for themselves as allies in scaling up alternative practices? Continual engagement of researchers or a full handover of a project to participants and practitioners, who can bide their time and make repeated attempts toward institutional change, can be one form of durable legacy. Indeed, the importance of involving practitioners and policy makers from the start, with a plan for subsequent hand-over, is the most important recommendation arising from our research as a precondition for successful scaling up and mainstreaming of alternative practices.

In conclusion, while the conceptual framework presented in this paper will serve as a valuable resource for future research on sustainable energy transition, our empirical analysis of case studies should support in bringing us all, researchers and practitioners, closer to scaling up of alternative, energy saving practices in the future.

\section{Acknowledgements}


The research presented here has received funding from the European Union's H2020 Research and Innovation programme under grant agreement number 727642, and from Academy of Finland under grant agreement number 315897. The sole responsibility for the content of this paper lies with the authors. The authors would like to thank the organisers of the PBIs studied. The authors gratefully acknowledge the valuable comments offered by Charlotte Louise Jensen and Henrike Rau on a draft version of this paper, as well as the anonymous reviewers for their in-depth comments and constructive suggestions, which helped to improve the quality of the article considerably. The authors also thank the participants of the ERSCP 2019 conference for their valuable comments on an earlier version of the paper. 


\section{References}

[1] Jensen, C.L., Fahy, F., Goggins, G., et al., 2017. Comprehensive Open Access Dataset of Sustainable Energy Consumption Initiatives (SECIs). ENERGISE, Deliverable 2.3. Online: http://www.energise-project.eu/sites/default/files/content/ENERGISE_D2.3_291117_final.pdf

[2] Keller, M., Halkier, B., Wilska, T., 2016. Policy and Governance for Sustainable Consumption at the Crossroads of Theories and Concepts. Environmental Policy and Governance, 26, 75-88. https://doi.org/10.1002/eet.1702

[3] Jensen, C. L., Goggins, G., Fahy, F., et al., 2018. Towards a practice-theoretical classification of sustainable energy consumption initiatives: Insights from social scientific energy research in 30 European countries. Energy Research \& Social Science, 45, 297-306.

[4] Strengers, Y., Pink, S., Nicholls, L., 2019. Smart energy futures and social practice imaginaries: Forecasting scenarios for pet care in Australian homes. Energy Research \& Social Science, 48, 108115. https://doi.org/10.1016/j.erss.2018.09.015

[5] Welch, D., Southerton, D., 2019. After Paris: transitions for sustainable consumption. Sustainability: Science, $\quad$ Practice, and Policy, 15(1), 31-44. https://doi.org/10.1080/15487733.2018.1560861

[6] Shove, E., Walker, G., 2010. Governing transitions in the sustainability of everyday life. Research Policy, 39(4), 471-476.

[7] Sahakian, M., Bertho, B., 2018. Exploring emotions and norms around Swiss household energy usage: when methods inform understandings of the social. Energy Research and Social Sciences, 45, 81-90.

[8] Heiskanen, E., Laakso, S., Matschoss, K., et al., 2018. Designing Real-World Laboratories for the Reduction of Residential Energy Use. Articulating Theories of Change. GAIA, 27(S1), 60-67.

[9] Seyfang, G., 2010. Community action for sustainable housing: Building a low-carbon future. Energy Policy, 38(12), 7624-7633.

[10] Seyfang, G., Haxeltine, A., 2012. Growing grassroots innovations: exploring the role of community-based initiatives in governing sustainable energy transitions. Environment and Planning C: Government and Policy, 30(3), 381-400. 
[11] Porter, N., Claassen, M., Timmermans, J., 2015. Transition experiments in Amsterdam: Conceptual and empirical analysis of two transition experiments in the WATERgraafsmeer program. Technological Forecasting and Social Change, 90, 525-537.

[12] Loorbach, D., Rotmans, J., 2006. Managing transitions for sustainable development. In: Understanding Industrial Transformation. Springer, Dordrecht, 187-206.

[13] Naber, R., Raven, R., Kouw, M., Dassen, T., 2017. Scaling up sustainable energy innovations. Energy Policy, 110, 342-354

[14] Lawrence, T. B., Suddaby, R., 2006. Institutions and institutional work. In: The Sage handbook of organization studies, 215-254.

[15] Köhler, J., Geels, F. W., Kern, F. et al., 2019. An agenda for sustainability transitions research: State of the art and future directions. Environmental Innovation and Societal Transitions 31, 1-32.

[16] Schatzki, T., 2016. Practice theory as flat ontology. In: Practice theory and research: Exploring the dynamics of social life, 28-42.

[17] Geels, F. W., 2011. The multi-level perspective on sustainability transitions: Responses to seven criticisms. Environmental innovation and societal transitions, 1(1), 24-40.

[18] Garud, R., Hardy, C., Maguire, S., 2007. Institutional entrepreneurship as embedded agency: An introduction to the special issue. Organization Studies 28, 957-969.

[19] Warde, A., 2005. Consumption and Theories of Practice. Journal of Consumer Culture, 5(2), 131-153. https://doi.org/10.1177/1469540505053090

[20] Gram-Hanssen, K., 2011. Understanding change and continuity in residential energy consumption. Journal of Consumer Culture, 11, 61-78. https://doi.org/10.1177/1469540510391725

[21] Shove, E., 2003. Comfort, cleanliness and convenience: the social organization of normality. Berg.

[22] Shove, E., Pantzar, M., Watson, M., 2012. The dynamics of social practice: Everyday life and how it changes. Sage.

[23] Laakso, S., Heiskanen, E., Matschoss, K., 2017. ENERGISE Living Labs background report. ENERGISE, Deliverable $3.2 . \quad$ Online: http://www.energiseproject.eu/sites/default/files/content/ENERGISE_D3.2_141117_FINAL_0.pdf 
[24] Devaney, L., Davies, A.R., 2017. Disrupting household food consumption through experimental HomeLabs: Outcomes, connections, contexts. Journal of Consumer Culture, 17(3), 823-844.

[25] Laakso, S., Jensen, C.L., Vadovics, E., et al., 2019. Towards sustainable and sufficient energy consumption: Challenging heating-related practices in Denmark, Finland and Hungary. Proceedings of the 19th European Roundtable for Sustainable Consumption and Production. Circular Europe for Sustainability: Design, Production and Consumption, 25-40.

[26] Godin, L., Laakso, S., Sahakian, M., 2020. Doing laundry in consumption corridors: Wellbeing and everyday life. Sustainability: Science, Practice and Policy, 16(1), 99-113.

[27] Dijk, M., de Kraker, J., Hommels, A., 2018. Anticipating Constraints on Upscaling from Urban Innovation Experiments. Sustainability, 10(8), 2796.

[28] Laakso, S., 2019. Experiments in Everyday Mobility: Social Dynamics of Achieving a Sustainable Lifestyle. Sociological Research Online, 24(2), 235-250.

[29] Laakso, S., Lettenmeier, M., 2016. Household-level transition methodology towards sustainable material footprints. Journal of Cleaner Production, 132, 184-191.

[30] Heiskanen, E., Laakso, S., 2019. Editing out unsustainability from consumption: From information provision to nudging and social practice theory. In: O. Mont (Ed), A Research Agenda for Sustainable Consumption Governance. Elgar Research Agendas, 156-171.

[31] Laakso, S., 2017. A practice approach to experimental governance. Experiences from the intersection of everyday life and local experimentation. Doctoral dissertation, University of Helsinki.

[32] Strengers, Y., Maller, C., 2012. Materialising energy and water resources in everyday practices: Insights for securing supply systems. Global Environmental Change, 22(3), 754-763.

[33] Pantzar, M., Shove, E., 2010. Understanding innovation in practice: a discussion of the production and re-production of Nordic Walking. Technology Analysis and Strategic Management, 22(4), 447-461.

[34] Schot, J., Geels, F., 2008. Strategic Niche Management and Sustainable Innovation Journeys: Theory, Findings, Research Agenda, and Policy. Technology Analysis and Strategic Management, 20(5), 537-54.

[35] Smith, A., Seyfang, G., 2013. Constructing grassroots innovations for sustainability. Global Environmental Change, 23(5), 827-829. 
[36] Shove, E., Pantzar, M., 2005. Consumers, producers and practices: Understanding the invention and reinvention of Nordic walking. Journal of Consumer Culture, 5(1), 43-64.

[37] Cashmore, M., Wejs, A., 2014. Constructing legitimacy for climate change planning: a study of local government in Denmark. Global Environmental Change, 24, 203-212.

[38] Raven, R.P., Heiskanen, E., Lovio, R., et al., 2008. The contribution of local experiments and negotiation processes to field-level learning in emerging (niche) technologies: meta-analysis of 27 new energy projects in Europe. Bulletin of Science, Technology and Society, 28(6), 464-477.

[39] Czarniawska-Joerges, B., Sevón, G., (Eds), 2005. Global ideas: how ideas, objects and practices travel in a global economy. Copenhagen Business School Press.

[40] Tracey, P., Phillips, N., Jarvis, O., 2011. Bridging institutional entrepreneurship and the creation of new organizational forms: A multilevel model. Organization Science, 22(1), 60-80.

[41] Warde, A., 2013. What sort of practice is eating? In E. Shove \& N. Spurling (Eds.), Sustainable practices. Social theory and climate change. London/ New York: Routledge, 17-30.

[42] Geels, F.W., 2006. The hygienic transition from cesspools to sewer systems (1840-1930): the dynamics of regime transformation. Research Policy, 35(7), 1069-1082.

[43] Hargreaves, T., Hielscher, S., Seyfang, G., Smith, A., 2013. Grassroots innovations in community energy: The role of intermediaries in niche development. Global environmental change, 23(5), 868-880.

[44] Heiskanen, E., Kivimaa, P., Lovio, R., 2019. Promoting sustainable energy: Does institutional entrepreneurship help? Energy Research and Social Science, 50, 179-190.

[45] Wijen, F., Ansari, S., 2007. Overcoming Inaction through Collective Institutional Entrepreneurship: Insights from Regime Theory. Organization Studies, 28(7), 1079-1100.

[46] Jolly, S., Spodniak, P., Raven, R.P.J.M., 2016. Institutional entrepreneurship in transforming energy systems towards sustainability: Wind energy in Finland and India. Energy Research and Social Science, 17, 102-118.

[47] Heiskanen, E., Jalas, M., Rinkinen, J., Tainio, P., 2015. The local community as a 'low-carbon lab': Promises and perils. Environmental Innovation and Societal Transitions, 14, 149-164. 
[48] Elzen, B., Van Mierlo, B., Leeuwis, C., 2012. Anchoring of innovations: Assessing Dutch efforts to harvest energy from glasshouses. Environmental innovation and societal transitions, 5, 1-18. Energy Suffizienz. Project Homepage. Online: https://energiesuffizienz.wordpress.com/

[49] Genus, A., Jensen, C. L., 2019. Beyond "Behaviour": the Institutionalisation of Practice and the Case of Energy-efficient Lighting in Denmark. Journal of Consumer Culture, 19(3), 340-358.

[50] Beckert, J., 2010. How do fields change? The interrelations of institutions, networks, and cognition in the dynamics of markets. Organization Studies, 31(5), 605-627.

[51] Seyfang, G. and Longhurst, N., 2013. Desperately seeking niches: Grassroots innovations and niche development in the community currency field. Global Environmental Change, 23(5), 881-891.

[52] Buhr, K., 2012. The inclusion of aviation in the EU emissions trading scheme: Temporal conditions for institutional entrepreneurship. Organization Studies, 33(11), 1565-1587.

[53] Boasson, E.L., Wettestad, J., 2014. Policy invention and entrepreneurship: bankrolling the burying of carbon in the EU. Global Environmental Change, 29, 404-412.

[54] Kautto, P., Similä, J., 2005. Recently introduced policy instruments and intervention theories. Evaluation, 11(1), 55-68.

[55] Mayne, J., 2015. Useful theory of change models. Canadian Journal of Program Evaluation, $30(2)$.

[56] Wolff, F., Schönherr, N., 2011. The impact evaluation of sustainable consumption policy instruments. Journal of Consumer Policy, 34(1), 43-66.

[57] Vedung, E., 2017. Public policy and program evaluation. London/New York: Routledge.

[58] Yin, R.K., 2014. Case Study Research Design and Methods (5th ed.). Thousand Oaks, CA: Sage.

[59] Korhonen, K., Matschoss K., 2017. Ilmastokatu. Smart Energy Transition -hanke. Online: http://smartenergytransition.fi/wp-content/uploads/2017/08/WP-4-Case-Ilmastokatu.pdf

[60] Seppälä, A., Haanpää, S., Klein, J., Juhola, S., 2017. Kokeilujen kautta hiilineutraaleihin kaupunkeihin? - Ilmastokatu-hankkeen arviointiraportti. (Carbon-neutral cities via experimentation? Evaluation report of the Climate Street project). Aalto-yliopiston julkaisusarja TIEDE + TEKNOLOGIA, 2/2017. Online: https://aaltodoc.aalto.fi/handle/123456789/28399

[61] Ilmastotreeni. Homepage. Online: https://ilmastotreeni.fi/ [accessed 1.6.2020] 
[62] Davies, A., Fahy, F., Rau, H. et al., 2014. CONSENSUS: Consumption, Environment and Sustainability. Dublin: EPA.

[63] Davies, A., Lavelle, M.J., Doyle, R., 2015. WASHLab: Summary analysis. Trinity College Dublin. Online: http://www.consensus.ie/wp/sample-page/papers-reports/

[64] Lavelle, M.J., Rau, H., Fahy, F., 2015. Different shades of green?: unpacking habitual and occasional pro-environmental behaviour. Global Environmental Change, 35, 368-378.

[65] Rau, H., Davies, A.R., Fahy, F., 2014. Conclusion: Moving on - promising pathways to more sustainable futures. In: A.R. Davies and et al., (Eds) Challenging Consumption: Pathways to a more Sustainable Future. London: Routledge, 187-205.

[66] Rau, H., Goggins, G., Fahy, F., 2018. From invisibility to impact: Recognising the scientific and societal relevance of interdisciplinary sustainability research. Research Policy, 47(1), 266-276.

[67] CONSENSUS. Project homepage. Online: http://www.consensus.ie/wp/homelab/ [accessed 1.6.2020]

[68] Brischke, L.-A., Köhler, T., 2017. (Energie-)Suffizienz als Handlungsfeld und als innovatives Organisationsmodell zukünftiger Bürgerenergiegenossenschaften. Energiesuffizienz projet. Online: https://energiesuffizienz.files.wordpress.com/2017/07/brischke-kc3b6hler-energie-suffizienz-alshandlungsfeld-und-als-innovatives-organisationsmodell-zukc3bcnftigerbc3bcrgerenergiegenossenschaften-1.pdf

[69] Brischke, L.-A., Lehmann, F., Leuser, L. et al., 2015. Energy sufficiency in private households enabled by adequate appliances. Online: https://energiesuffizienz.files.wordpress.com/2015/05/7294-15_brischke_final.pdf

[70] Grealis, E., Musch, A., Rau, H., 2018. Country report: Germany. Extracted from Jensen et al. (2017) Production of 30 national summary briefs. ENERGISE, Deliverable 2.5. Online: http://www.energise-project.eu/sites/default/files/content/D2.5_Germany.pdf

[71] Thomas, S., Brischke, L.A., Thema, J., Kopatz, M., 2015. Energy sufficiency policy: an evolution of energy efficiency policy or radically new approaches? ECEEE Summer Study Proceedings, 59-70. Online: https://epub.wupperinst.org/frontdoor/deliver/index/docId/5922/file/5922_Thomas.pdf

[72] Thomas, S., Thema, J., Brischke, L.A., et al., 2019. Energy sufficiency policy for residential electricity use and per-capita dwelling size. Energy Efficiency, 12(5), 1123-1149. 
[73] Wagner, O., Bierwirth, A. and Thema, J., 2019. The building battlefield: (in)consistencies in German policies for sustainable living. ECEEE Summer Study Proceedings 439. Online: https://epub.wupperinst.org/frontdoor/deliver/index/docId/7330/file/7330_Wagner.pdf

[74] Energiesuffizienz. Project website. Online: https://energiesuffizienz.wordpress.com/ [accessed 1.6.2020]

[75] Lettenmeier, M. et al., 2015. Tulevaisuuden kotitalous - Resurssiviisaan arjen tavat ja palvelut, Helsinki. Online: https://media.sitra.fi/2017/02/23070648/tulevaisuuden_kotitalous_loppuraportti3.pdf

[76] Tulevaisuuden kotitalous. Project https://www.sitra.fi/hankkeet/tulevaisuuden-kotitalous/ [accessed 1.6.2020]

[77] RII Tools, 2015. KlimaAlltag - low carbon lifestyles in the zero emissions city. Online: https://www.rri-tools.eu/-/kilmaalltag_insp_practice

[78] Stiess, I., 2013. Klimafreundlich leben in der Stadt. Potenziale für CO2-arme Lebensstile. Publication of the project KlimaAlltag. Online: http://www.klimaalltag.de/fileadmin/redaktion/downloads/klimaalltag-broschuere-2013.pdf

[79] Waskow, F., Pannenbecker, S., 2013. Empfehlungen für eine verhaltensorientierte Klimaberatung. Arbeitspapier. Online: http://www.klima-alltag.de/uploads/media/klimaalltagarbeits-papier-klimaberatung-vznrw-2013_03.pdf

[80] KlimaAlltag. Project Summary. Online: http://www.klima-alltag.de/Startseite.15.0.html [accessed 1.6.2020]

[81] Hoff, J., 2015. Hvad er potentialet i borgerdrevne klimaprojekter? (What is the potential of citizen-driven climate projects?) NYTFOKUS Newsletter 5. Online: http://nytfokus.nu/nummer5/borgerdrevne-klimaprojekter/

[82] Hoff, J., 2015. Co-creation of climate change mitigation policies: the superiority of a communitybased approach. Paper presented at Nordic Environmental Social Science (NESS) Conference, Trondheim, Norway, June 2015.

[83] Papazu, I., 2015. On the Materialisation of Participation in a Municipality Near You. In: J. Hoff and Q. Gausset (Eds). Community Governance and Citizen-Driven Initiatives in Climate Change Mitigation. London/New York: Routledge, 54-68. 
[84] Røpke, I. and Jensen, C., 2018. Country report: Denmark. Extracted from Jensen et al. (2017) Production of 30 national summary briefs. ENERGISE, Deliverable 2.5. Online: http://www.energise-project.eu/sites/default/files/content/D2.5_Denmark.pdf

[85] Kanger, L., Sovacool, B., Noorkõiv, M., 2020. Six policy intervention points for sustainability transitions: A conceptual framework and a systematic literature review. Research Policy, 49(7), 104072.

[86] Southerton, D., 2013. Habits, routines and temporalities of consumption: From individual behaviours to the reproduction of everyday practices. Time \& Society, 22(3), 335-355. 